\section{Copulatory behavior of male rats following reserpine administration*}

\author{
DONALD A. DEWSBURY \\ University of Florida, Gainesville, Fla. 32601
}

Two experiments were conducted further to specify the effects of reserpine on copulatory behavior in male rats. In Experiment 1, multiple doses of $0.5 \mathrm{mg} / \mathrm{kg}$ reserpine produced significant reductions in the number of intromissions required to attain ejaculation, as well as changes in two other measures. In Experiment 2, intromission frequency in the second series was reduced following a single injection of $1.0 \mathrm{mg} / \mathrm{kg}$ reserpine. Data from experiments on reserpine reveal a specific facilitatory effect on intromission frequency, which is consistent with the hypothesis that high brain monoamine level inhibits ejaculation.

Short-term administration of reserpine facilitates the copulatory behavior of male rats (Soulairac \& Soulairac, 1961, 1962; Soulairac, 1963; Dewsbury \& Davis, 1970). This effect is particularly interesting for two reasons. First, it is a facilitative effect and thus in contrast to most behavioral effects of reserpine (Pirch, Rech, \& Moore, 1967; Carlson, Doyle, \& Bidder, 1965; Ray, 1963; John, Wenzel, \& Tschirgi, 1958). Second, the facilitation may be specific to one aspect of the total pattern-the number of intromissions required to attain ejaculation.

Evidence accumulated by Beach (1967) and Hart (1968) suggests that the reflexes of the consummatory portions of copulatory behavior are organized in the spinal cord and inhibited by higher structures. Data on effects of reserpine are especially important because, together with recent data on $\mathrm{p}$-chlorophenylalanine (Shillito, 1969; Tagliamonte, Tagliamonte, Gessa, \& Brodie, 1969; Ferguson et al, 1970), they suggest the possibility that high brain monoamine levels may play a role in this inhibition (Dewsbury \& Davis, 1970). The system, as conceived, would be broadly analogous to that proposed for the control of the estrus behavior of females by Meyerson (1964).

The two experiments to be reported were designed to replicate and extend the phenomena previously reported. Although the most striking and consistent effect of reserpine has been upon intromission frequency, Soulairac \& Soulairac (1961) also reported two instances of reductions in duration of the postejaculatory interval. The failure of Dewsbury \& Davis (1970) to replicate this phenomenon may be attributable to

* This research was supported by Grants GB-6590 and GB-12941 from the National Science Foundation. Hormones were provided through the courtesy of Dr. Preston L. Perlman of the Schering Corporation, Bloomfield, New Jersey. procedural differences rather than specific action of reserpine. Whereas the Soulairacs used multiple injections at 0.25 and $0.60 \mathrm{mg} / \mathrm{kg}$, Dewsbury and Davis used single injections at 0.5 and $1.0 \mathrm{mg} / \mathrm{kg}$. The effects of multiple injections were studied in Experiment 1. Secondly, whereas Soulairac and Soulairac obtained significant differences in the first series, in addition to later series, Dewsbury and Davis did not. To test this phenomenon further, Experiment 2 is presented as a systematic replication with extension to two different injection-test intervals.

\section{EXPERIMENT \\ Method}

The Ss were 16 male Long-Evans rats purchased from a commercial supplier; they were 110 days of age at

Table 1

Mean Scores and Results of Statistical Analyses of Experiment 1

\begin{tabular}{|c|c|c|c|c|c|c|c|}
\hline \multirow[b]{2}{*}{ Measure } & \multirow[b]{2}{*}{ Drug } & \multicolumn{4}{|c|}{ Mean Score on Day } & \multirow[b]{2}{*}{$F$} & \multirow[b]{2}{*}{$\mathbf{p}$} \\
\hline & & 0 & 3 & 6 & 9 & & \\
\hline $\begin{array}{l}\text { ML } \\
\text { (Sec) }\end{array}$ & $\begin{array}{l}\text { Saline } \\
\text { Reserpine }\end{array}$ & $\begin{array}{l}9.8 \\
8.9\end{array}$ & $\begin{array}{r}11.6 \\
7.9\end{array}$ & $\begin{array}{l}7.1 \\
7.8\end{array}$ & $\begin{array}{l}7.8 \\
9.8\end{array}$ & $<1$ & - \\
\hline $\begin{array}{l}\text { IL } \\
\text { (Sec) }\end{array}$ & $\begin{array}{l}\text { Saline } \\
\text { Reserpine }\end{array}$ & $\begin{array}{r}118.7 \\
48.9\end{array}$ & $\begin{array}{l}23.4 \\
33.1\end{array}$ & $\begin{array}{l}27.3 \\
12.8\end{array}$ & $\begin{array}{l}77.2 \\
22.1\end{array}$ & 1.10 & - \\
\hline $\begin{array}{l}\text { EL-1 } \\
(\mathrm{Sec})\end{array}$ & $\begin{array}{l}\text { Saline } \\
\text { Reserpine }\end{array}$ & $\begin{array}{l}561.5 \\
628.6\end{array}$ & $\begin{array}{l}367.4 \\
320.6\end{array}$ & $\begin{array}{l}415.1 \\
283.1\end{array}$ & $\begin{array}{l}440.8 \\
367.8\end{array}$ & 3.24 & - \\
\hline IF -1 & $\begin{array}{l}\text { Saline } \\
\text { Reserpine }\end{array}$ & $\begin{array}{l}8.5 \\
8.8\end{array}$ & $\begin{array}{r}10.1 \\
9.2\end{array}$ & $\begin{array}{l}9.3 \\
6.9\end{array}$ & $\begin{array}{r}10.6 \\
6.9\end{array}$ & 6.84 & $<.05$ \\
\hline$M F-1$ & $\begin{array}{l}\text { Saline } \\
\text { Reserpine }\end{array}$ & $\begin{array}{l}8.4 \\
8.5\end{array}$ & $\begin{array}{l}5.6 \\
5.9\end{array}$ & $\begin{array}{l}8.6 \\
3.3\end{array}$ & $\begin{array}{r}10.2 \\
4.6\end{array}$ & 3.30 & - \\
\hline $\begin{array}{l}\text { MIII-1 } \\
\text { (Sec) }\end{array}$ & $\begin{array}{l}\text { Saline } \\
\text { Reserpine }\end{array}$ & $\begin{array}{l}59.4 \\
71.5\end{array}$ & $\begin{array}{l}33.0 \\
35.8\end{array}$ & $\begin{array}{l}35.0 \\
39.1\end{array}$ & $\begin{array}{l}34.9 \\
48.7\end{array}$ & 1.84 & - \\
\hline $\begin{array}{l}\text { PEI-1 } \\
(\mathrm{Sec})\end{array}$ & $\begin{array}{l}\text { Saline } \\
\text { Reserpine }\end{array}$ & $\begin{array}{l}351.5 \\
388.3\end{array}$ & $\begin{array}{l}390.2 \\
398.8\end{array}$ & $\begin{array}{l}411.6 \\
394.8\end{array}$ & $\begin{array}{l}408.1 \\
400.7\end{array}$ & 1.76 & - \\
\hline $\begin{array}{l}\text { EL-2 } \\
(\mathrm{Sec})\end{array}$ & $\begin{array}{l}\text { Saline } \\
\text { Reserpine }\end{array}$ & $\begin{array}{l}223.1 \\
283.3\end{array}$ & $\begin{array}{l}301.4 \\
162.6\end{array}$ & $\begin{array}{l}309.1 \\
181.2\end{array}$ & $\begin{array}{l}264.5 \\
303.7\end{array}$ & 5.01 & $<.05$ \\
\hline $1 F-2$ & $\begin{array}{l}\text { Saline } \\
\text { Reserpine }\end{array}$ & $\begin{array}{l}4.8 \\
5.1\end{array}$ & $\begin{array}{l}6.6 \\
3.9\end{array}$ & $\begin{array}{l}6.6 \\
2.9\end{array}$ & $\begin{array}{l}6.6 \\
3.0\end{array}$ & 22.50 & $<.01$ \\
\hline MF-2 & $\begin{array}{l}\text { Saline } \\
\text { Reserpine }\end{array}$ & $\begin{array}{l}3.1 \\
5.1\end{array}$ & $\begin{array}{l}5.3 \\
2.6\end{array}$ & $\begin{array}{l}4.7 \\
1.3\end{array}$ & $\begin{array}{l}3.4 \\
1.8\end{array}$ & 12.52 & $<.01$ \\
\hline $\begin{array}{l}\text { MIII-2 } \\
\text { (Sec) }\end{array}$ & $\begin{array}{l}\text { Saline } \\
\text { Reserpine }\end{array}$ & $\begin{array}{l}45.2 \\
53.0\end{array}$ & $\begin{array}{l}39.8 \\
38.5\end{array}$ & $\begin{array}{l}44.4 \\
60.7\end{array}$ & $\begin{array}{r}36.0 \\
106.4\end{array}$ & 2.20 & - \\
\hline
\end{tabular}

the beginning of the experiment. They had received preliminary handling and two tests of copulatory behavior prior to the experiment. The males were mated with 20 female rats of the same age and strain.

All tests were conducted in Plexiglas arenas which were $76-84 \mathrm{~cm}$ in diam and $61-66 \mathrm{~cm}$ high. Arenas were placed on wooden bases covered with a commercially produced litter material. All copulatory events were recorded manually on an Esterline-Angus operations recorder.

Each male received eight tests of copulatory behavior, organized in two four-test blocks. One block of tests was designed to test the effects of reserpine administration and one block as a control using saline. The first test of each block was conducted on the afternoon of Day 0. Following this test, each rat received an intraperitoneal injection of either $0.5 \mathrm{mg} / \mathrm{kg}$ body weight of reserpine (Ciba Serpasil) or the appropriate volume of saline. Half of the rats received each treatment first as determined at random. Daily injections continued to 9 days, with tests of copulatory behavior on Days 3,6 , and 9 . Following a 19-day rest period, the procedure was repeated, but with each rat receiving the treatment opposite to that received in the first test block. Thus, each animal served as its own control.

All tests were initiated $3-4 \mathrm{~h}$ after onset of the dark phase of the light-dark cycle. Males were permitted $5 \mathrm{~min}$ in the arenas prior to 
Table 2

Mean Scores and Results of Statistical Analyses of Experiment 4

\begin{tabular}{|c|c|c|c|c|c|c|c|c|c|c|c|c|}
\hline \multirow{2}{*}{$\begin{array}{c}\text { Injection- } \\
\text { Test } \\
\text { Interval }\end{array}$} & \multirow{2}{*}{$\begin{array}{c}\text { Condition } \\
\text { and } \\
\text { Statistic }\end{array}$} & \multicolumn{11}{|c|}{ Measure } \\
\hline & & $\mathrm{ML}$ & IL & EL-1 & IF - 1 & MF-1 & MIII-1 & PEI-1 & EL-2 & IF -2 & $M F-2$ & MIIII-2 \\
\hline $4 \mathrm{~h}$ & $\begin{array}{l}\text { Saline } \\
\text { Reserpine }\end{array}$ & $\begin{array}{l}52.2 \\
65.6\end{array}$ & $\begin{array}{l}156.2 \\
221.9\end{array}$ & $\begin{array}{l}1142.3 \\
1000.7\end{array}$ & $\begin{array}{r}10.1 \\
9.2\end{array}$ & $\begin{array}{l}8.2 \\
8.4\end{array}$ & $\begin{array}{l}108.3 \\
105.1\end{array}$ & $\begin{array}{l}471.2 \\
503.9\end{array}$ & $\begin{array}{l}424.8 \\
368.5\end{array}$ & $\begin{array}{l}5.4 \\
4.9\end{array}$ & $\begin{array}{l}3.9 \\
3.0\end{array}$ & $\begin{array}{l}76.8 \\
80.1\end{array}$ \\
\hline $24 \mathrm{~h}$ & $\begin{array}{l}\text { Saline } \\
\text { Reserpine } \\
\text { F } \\
\text { p }\end{array}$ & $\begin{array}{c}107.6 \\
212.8 \\
1.32 \\
-\end{array}$ & $\begin{array}{c}127.2 \\
549.3 \\
2.81 \\
-\end{array}$ & $\begin{array}{c}1152.9 \\
898.8 \\
0.91 \\
-\end{array}$ & $\begin{array}{l}10.9 \\
8.9 \\
4.17 \\
-\end{array}$ & $\begin{array}{l}8.6 \\
7.3 \\
0.15 \\
-\end{array}$ & $\begin{array}{c}96.5 \\
100.3 \\
0.00 \\
-\end{array}$ & $\begin{array}{c}458.3 \\
522.1 \\
1.73 \\
-\end{array}$ & $\begin{array}{c}581.8 \\
395.0 \\
3.09 \\
-\end{array}$ & $\begin{array}{c}7.1 \\
4.7 \\
10.65 \\
<.05\end{array}$ & $\begin{array}{l}4.5 \\
3.3 \\
3.16 \\
-\end{array}$ & $\begin{array}{c}71.9 \\
72.4 \\
0.05 \\
-\end{array}$ \\
\hline
\end{tabular}

introduction of the females, which constituted the beginning of the tests. Tests were continued until the second ejaculation was attained.

Females were brought into behavioral estrus with intramuscular injections of $0.1 \mathrm{mg}$ estradiol benzoate, $75 \mathrm{~h}$ before testing, and $0.1 \mathrm{mg}, 3-6 \mathrm{~h}$ before testing. Only receptive females were used in tests.

Copulatory behavior in rats is organized in series of vaginal intromissions, with each series terminated by an ejaculation. The following measures were taken: mount latency (ML)-latency from introduction of the female to the first mount with thrusting; intromission latency (IL)-latency to the first intromission; ejaculation latency (EL)-latency from the first intromission of a series to the ejaculation; intromission frequency (IF)-the number of intromissions in the series; mount frequency (MF)-the number of mounts in a series; mean in terintromission interval (MIII)-mean interval separating the intromissions of a series; and postejaculatory interval (PEI)-latency from the ejaculation to the resumption of copulation, as indicated by the first intromission of the subsequent series. Results

The mean scores on each day and the results of statistical analyses are presented in Table 1. In order to render the data readily amenable to analysis of variance, the scores from Days 3,6 , and 9 were expressed as differences from the Day 0 baseline, and a constant was added to make all numbers positive. Three-way analyses of variance with repeated measures were performed. Reserpine produced significant reductions in IF-1, IF-2, EL-2, and MF-2. All of the differences in the second series were apparent by Day $3 \quad[t(I F-2)=3.41, \quad p<.05$; $\mathrm{t}(\mathrm{MF}-2)=3.09, \quad \mathrm{p}<.05$ $t(E L-2)=2.33, p<.05]$. The effect of reserpine on IF-1 was not apparent after 3 days of treatment $(t=0.99$, $\mathrm{p}>.05$ ), but was apparent by Day 6 $(t=2.84, p<.05)$. No other measures showed significant variation.

\section{EXPERIMENT 2 \\ Methods}

The Ss were 12 male Long-Evans rats, 140 days of age at the beginning of the experiment. They were mated with 16 females of the same age and strain.

Each male received four tests of copulatory behavior spaced 2 weeks apart. Tests were conducted either 4 or $24 \mathrm{~h}$ after a single injection of either $1.0 \mathrm{mg} / \mathrm{kg}$ reserpine or an equivalent volume of saline. Each male was assigned randomly to one of four balanced testing orders.

All other procedures were identical to those of Experiment 1.

$$
\text { Results }
$$

The results of Experiment 2 are presented in Table 2. Data were analyzed with three-way analyses of variance with repeated measures. The only measure to show significant variation was IF-2. Although IF-2 was reduced significantly $24 \mathrm{~h}$ after the single reserpine injection $(t=2.64$, $\mathrm{p}<.05$ ), there was no significant effect at $4 \mathrm{~h}(\mathrm{t}=0.55, \mathrm{p}>.05)$. The high IF-2 at $24 \mathrm{~h}$ following saline was attributable to one animal with an IF-2 of 19. Ten of the 12 males showed a reduction in IF at $24 \mathrm{~h}$. Neither the main effect of injection-test interval nor its interaction with drug condition was significant. The effect of drug on IF-1 was not significant $(F=4.17$; $.10>\mathrm{p}>.05$ ).

\section{DISCUSSION}

Reduction in intromission frequency following administration of reserpine is revealed to be a reliable phenomenon. Such reductions were obtained in both experiments. The specificity of the effect is established. The only other alterations seen were in EL-2 and MF-2 in Experiment 1. Alterations in EL when IF is changed are interpretable as secondary to the changes in IF. As there are fewer intromissions required to attain ejaculation, less time is required. There is no obvious explanation for the reduction in MF-2 in Experiment 1. No such significant effect was obtained by Dewsbury \& Davis (1970) or in Experiment 2. There was no suggestion of any reduction in PEI like that obtained by Soulairac \& Soulairac (1961) in either the two present experiments or that of Dewsbury \& Davis (1970). Thus, the changes in PEI and MF may be a function of some condition specific to individual experiments. Only changes in IF appear consistently in every experiment.

Although there is some indication that brain monoamine levels are not completely returned to normal levels at the end of the 14- to 19-day intertest intervals used in the present experiments (Haggendal \& Lindquist, $1964 \mathrm{a}, \mathrm{b})$, the effects obtained are virtually identical to those obtained with longer between-test intervals (Dewsbury \& Davis, 1970). Thus, between-test interval in this range does not appear to be a major factor for the effect of reserpine on copulatory behavior.

Prolonged administration of $0.6 \mathrm{mg} / \mathrm{kg}$ (Soulairac \& Soulairac, $1961)$ and single injections at $2.0 \mathrm{mg} / \mathrm{kg}$ in our pilot work results in a complete loss of copulatory behavior as the male remains in a stupor. Even longer chronic administration can interfere with copulatory behavior, presumably as a secondary effect of alterations in the endocrine system (Fuller, 1963).

It is notable that IF-2 is more sensitive to the effects of reserpine than is IF-1. Soulairac \& Soulairac (1961) obtained a significant reduction in IF-2 but not IF-1 following multiple doses of reserpine at $0.6 \mathrm{mg} / \mathrm{kg}$. In both Experiment 2 and in the data of Dewsbury \& Davis (1970), there was a significant reduction in IF-2 but not IF.1 following single injections at $1.0 \mathrm{mg} / \mathrm{kg}$. In Experiment 1 and in the data of Soulairac \& Soulairac (1961) at $0.25 \mathrm{mg} / \mathrm{kg}$, reductions in both $\mathrm{IF}-1$ and IF-2 were obtained. In Experiment 1, the $F$ ratio was larger for IF-2 than for IF-1. Further, the effect appeared at Day 3 for IF-2 but not until Day 6 for IF-1. The 
phenomenon of a greater sensitivity to experimental manipulation in the second series than in the first is not unique to drug studies (Dewsbury, 1969). It may be related to greater variability in the first series. This phenomenon is important in interpreting studies which were terminated after the first ejaculation. With such a procedure, important experimental effects may be overlooked.

The present data remain consistent with the hypothesis that high brain monoamine levels may inhibit ejaculation.

\section{REFERENCES}

BEACH, F. A. Cerebral and hormonal control of reflexive mechanisms involved in copulatory behavior. Physiological Reviews, 1967, 47, 289-316.

CARLSON, N. J., DOYLE, D. J., \& BIDDER, T. G. The effects of DL-amphetamine on runway performance. Psychopharmacologia. $1965,8,157-173$.

DEWSBURY, D. A. Copulatory behavior of rats (Rattus norvegicus) as a function of prior copulatory experience. Animal Behaviour, 1969, 17, 217-223.

DEWSBURY, D. A., \& DAVIS, H. N. Effects of reserpine on the copulatory behavior of male rats. Physiology \& Behavior, 1970, 5, 1331-1333.

FERGUSON, J., HENRIKSEN, S., COHEN, H. MITCHELL, G., BARCHAS, J., \& DEMENT, W. "Hypersexuality" and behavioral changes in cats caused by administration of p-chlorophenylalanine. Science, 1970, 168, 499-501.

FULLER, R. Sexual changes in the male rat following chronic administration of reserpine. Nature, $1963,200,585-586$.

HAGGENDAL, J., \& LINDQUIST. M. Disclosure of labile monoamine-fractions in brain and their correlation to behavior. Acta Physiologica Scandanavica, 1964a, 60, 351-357.

HAGGENDAL, J., \& LINDQUIST, M. Brain monoamine levels and behaviour during long-term administration of reserpine. International Journal of Neuropharmacology, 1965b, 3, 59-64.

HART, B. L. Sexual reflexes and mating behavior in the male rat. Journal of Comparative \& Physiological Psychology, $1968,65,453-460$.

JOHN, E. F., WENZEL, B. M., \& TSCHIRGI, $\ddot{R}$. D. Differential effects of reserpine on conditioned avoidance responses in cats. Science, 1958, 127, 25-26.

MEYERSON, B. J. Central nervous system monoamines and hormone induced estrus behavior in the spayed rat. Acta Physiologica Scandinavica, 1964, 63 (Supplement 241) 1-32.

PIRCH. J. H., RECH, R. H., \& MOORE. K. E. Depression and recovery of the electrocorticogram, behavior, and brain amines in rats treated with reserpine. International Journal of Neuropharmacology, 1967, 6, 375-385.

RAY, $O$. S. The effects of tranquilizers on positively and negatively motivated behavior in rats. Psychopharmacologia, 1963, 4, 326-342.

SHILLITO, E. E. The effect of $p-c h l o r o p h e n y l a l a n i n e$ on social interactions of male rats. British Journa of Pharmacology, 1969, 36, 193P-194P.

SOULAIRAC, M. L. Etude experimentale des regulations hormononerveuses du comportement sexuel du rat male. Annales D'Endrocinologie, 1963, 24 (Supplement), 1-98.
SOULAIRAC, A., \& SOLLAIRAC, M. L, Action de la reserpine sur le comportement sexuel du rat male. Comptes Rendus des Séances de la Societé de Biologie, 1961, 155, $1010-1013$.

SOULAIRAC, A., \& SOULAIRAC, M. L. Effects de l'administration chronique de reserpine sur la fonction genitale dur rate male. Annales D'Endocrinologie, 1962, $23,281-292$.

TAGLIAMONTE, A., TAGLIAMONTE, P. GESSA, G. L., \& BRODIE, B. B. Compulsive sexual activity induced by p-chlorophenylalanine in normal and pinealectomized male rats. Science, 1969 , $166,1433-1435$

\title{
Temperature variation during the estrous cycle: Active vs restricted rats
}

\author{
JACK H. MCLEAN and WILLIAM P. COLEMAN \\ Louisiana State University in New Orleans, New Orleans, La. 70122
}

Eight female hooded rats were divided into two groups, one active (unrestricted) and another severely restricted in muscular activity. Colonic temperatures and vaginal smears were taken daily to determine body temperature throughout one natural estrous cycle. Body temperatures for the active and restricted groups were about the same for all phases of the estrous cycle except early estrus. During this phase the restricted group, as predicted, demonstrated a much greater dip in temperature than did the active group. It was hypothesized that the increase in running activity one normally records during estrus is a temperature control mechanism rather than an indicant of increased drive.

For years workers have noted that food and water deprivation usually cause an increase in activity in the rat (Bevan et al, 1950; Finger, 1951). At the same time, muscular activity and its associated heat production is a means of maintaining body temperature (Brobeck et al, 1947). Brobeck was one of the first researchers to tie these two phenomena together in hypothesizing that the regulation of food intake is related to the regulation of body temperature (Brobeck, 1948). In 1957 Stevenson and Rixon published a unique study that tested the Brobeck hypothesis. They reasoned that rats whose muscular activity was severely restricted would be unable to use muscular exertion as a means of maintaining body temperature and would suffer a temperature decrease during deprivation. On the other hand, a restricted but free-feeding group or an active-deprived group should not experience a temperature drop, since they have food intake and muscular exertion, respectively, to achieve temperature homeostasis. To test these ideas, they divided their Ss into an active group, which was allowed to move freely, and a restricted group, in which the Ss were suspended from canvas slings to minimize muscular activity. Half of each group was then placed on a deprived food schedule and the other half on an ad lib food schedule. As predicted, only the restricted-deprived Ss suffered a temperature drop. The other three groups were able to maintain their body temperature. The authors concluded that, in the absence of the heat-producing calories available in food, muscular activity is used to compensate for the heat deficit. "It is suggested that the increased activity during starvation is related to the maintenance of body temperature and is interrelated with food intake in this function [p. 582]."

Also for years, psychologists have noted a large increase in running activity of the female during estrus (Munn, 1950; Slonaker, 1924; Wang, 1924 , 1927). Some have even suggested that this increased running is a good method of pinpointing estrus (Ericsson, 1953). A decline in body temperature immediately preceding this rise in running activity has likewise been reported (Brobeck, 1947). One might then hypothesize, along the same lines as Stevenson and Rixon for food deprivation, that this increased activity during estrus is related to the drop in temperature and serves as a means of maintaining the temperature of the animal.

Paralleling the Stevenson and Rixon study still further, might not one 